\title{
Robust antibody and cellular responses with an improved DNA vaccine alone
}

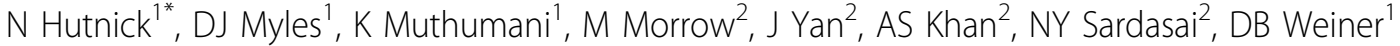 \\ From AIDS Vaccine 2012 \\ Boston, MA, USA. 9-12 September 2012
}

\section{Background}

The recent results of the RV144 trial demonstrate that HIV-specific antibodies may provide protection from infection. DNA vaccines may represent an important HIV vaccine platform since they are safe, relatively inexpensive to manufacture, and stable at room temperature. However, the platform has been used largely as a prime modality limited to induce low level CD4 $\mathrm{T}$ cell responses in NHP and humans. In this study we sought to improve our current DNA vaccines to induce HIVspecific antibodies with plasmid vaccination alone.

\section{Methods}

Groups of 5 Indian Rhesus Macaques were vaccinated with pHIV consensus gag, pol, and clade $C$ envelopes delivered IM with in-vivo electroporation at weeks 0,4 and 12 . Immunogenicity was measured two weeks after each dose.

\section{Results}

Three doses of an HIV DNA vaccine alone induced robust cellular and antibody responses. Despite using clade $\mathrm{C}$ based enveloped, high binding titers were detectable against gp120s from multiple clades. Neutralizing titers were in the 100's range to a panel of clade B and $C$ tier 1 viruses. These data establish that designed DNA envelop antigens can drive functional immunity in NHP.

\section{Conclusion}

Multiple improvements to DNA vaccine technology have significantly enhanced the immunogenicity of the platform. Just three doses of a plasmid based HIV vaccine induced robust binding and neutralizing antibodies as well as effector T-cell responses in NHP. We are

${ }^{1}$ University of Pennsylvania, Philadelphia, PA, USA

Full list of author information is available at the end of the article currently expanding the immunity induced by these constructs through novel DNA adjuvants as well as in prime-boost combinations.

\section{Author details}

'University of Pennsylvania, Philadelphia, PA, USA. ${ }^{2}$ Inovio Pharmaceuticals, Blue Bell, PA, USA.

Published: 13 September 2012

doi:10.1186/1742-4690-9-S2-P15

Cite this article as: Hutnick et al:: Robust antibody and cellular

responses with an improved DNA vaccine alone. Retrovirology 20129 (Suppl 2):P15.
Submit your next manuscript to BioMed Central and take full advantage of:

- Convenient online submission

- Thorough peer review

- No space constraints or color figure charges

- Immediate publication on acceptance

- Inclusion in PubMed, CAS, Scopus and Google Scholar

- Research which is freely available for redistribution
() Biomed Central 